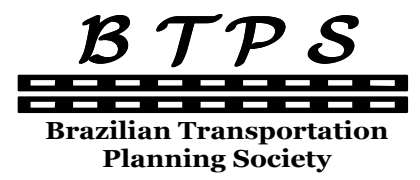

Journal of Transport Literature

Vol. 7, n. 2, pp. 373-402, Apr. 2013

Research Directory

JTL|RELIT

www.transport-literature.org ISSN 2238-1031

"William Grossman" Transport Economics Award Winner

\title{
Assessing the effects of the São Paulo's metropolitan beltway on residential land prices
}

[Avaliação dos efeitos do rodoanel paulistano nos preços de imóveis residenciais]

\author{
Vladimir Fernandes Maciel*, Ciro Biderman \\ Universidade Presbiteriana Mackenzie, Brazil, Fundação Getulio Vargas (FGV), Brazil
}

Submitted 15 Mar 2012; received in revised form 13 Aug 2012; accepted 5 Sep 2012

\begin{abstract}
This paper estimates the effect of highways on land prices using the implementation of the west branch of a large beltway around Sao Paulo Metropolitan Area. This is a unique opportunity since the beltway is being implemented by branches. So, it is possible to use the zones surrounding the branches where construction has actually started as a treatment group to be compared with zones surrounding branches for which construction has not started yet. Since we have a proxy for land price data before and after construction, it is possible to estimate the impact by difference-in-difference. The evidence is that there are significant and asymmetrical effects caused by the highway construction. Parcels located close to ramps outbound of the track observed an increase in price faster than similar zones close to other (planned) branches. For parcels located inbound of the beltway, relatively far from the track (between $2.5 \mathrm{~km}$ and $5 \mathrm{~km}$ ), the effects of construction and delivery/operation faced a (relative) decline in land prices. These results have consequences for transportation finance; betterment levies and value capture taxes; and welfare.
\end{abstract}

Key words: highway impact, hedonic prices, land outcomes, difference-in-difference, São Paulo beltway.

\section{Resumo}

Este artigo estima o efeito de uma nova rodovia sobre o preço do solo através da análise da implantação do trecho oeste do Rodoanel Metropolitano de São Paulo. Esta é uma oportunidade única, dado que o anel viário está sendo implantado em etapas. Sendo assim, é possível usar as zonas vizinhas ao traçado do trecho já construído como grupo de tratamento a ser comparado com as zonas que ainda não foram afetadas. Dado que temos uma proxy para o preço do solo antes e depois da construção, é possível estimar o impacto por diferença-em-diferença (dif-in-dif). A evidência apresentada é que existe impacto significativo e assimétrico causado pela construção da rodovia. Terrenos localizados no lado de fora do traçado construído tiveram aumento maior de preços do que aqueles localizados em zonas similares que são próximas dos demais trechos propostos. Para os terrenos localizados do lado de dentro do traçado, relativamente distante das alças de acesso (entre 2,5 e 5,0km), o efeito da implantação do trecho foi o relativo declínio dos preços do solo. Estes resultados são relevantes para as questões de financiamento dos transportes, contribuição de melhoria, taxas sobre mais-valia urbana e bem-estar.

Palavras-Chave: impacto de rodovias, preços hedônicos, resultados em terrenos, diferenças-em-diferenças, rodoanel paulistano.

*Email: vladimir.maciel@mackenzie.br.

\section{Recommended Citation}

Maciel, V. F. and Biderman, C. (2013) Assessing the effects of the São Paulo's metropolitan beltway on residential land prices. Journal of Transport Literature, vol. 7, n. 2, pp. 373-402.

- JTL/RELIT is a fully electronic, peer-reviewed, open access, international journal focused on emerging transport markets and published by BPTS - Brazilian Transport Planning Society. Website www.transport-literature.org. ISSN 2238-1031. 


\section{Introduction}

The purpose of this paper is to evaluate the effects of the announcement and construction of a large beltway (Rodoanel) around São Paulo Metropolitan Area (SPMA) on land prices. According to Wheaton (1977), one must take into account benefits and costs of road investments, which include more than the direct effects. Thus, one should look for indirect effects on land use and location decisions. One way to do that is to evaluating the impacts on land prices.

This kind of study can shed light on several planning and urban policy questions, as pointed by Bouarnet \& Charlermpong (2001). Urban economic theory states that, coeteris paribus, land value will be higher in locations that are more accessible to Central Business Districts (CBD) or other employment destinations. In order to test this hypothesis we choose Rodoanel which is the greatest road investment in the state of São Paulo. Rodoanel is a beltway around the city of São Paulo which surrounds its metropolitan area. The project of Rodoanel is divided into four sections. Currently (2012) there are two sections finished: the West and the South branch. In this paper we estimate the impact of Rodanel announcement and construction on residential land prices a posteriori.

Rodoanel is one of the biggest urban transport investments in Latin America and it has several interesting features. First the amount of the investment-US\$ 1.6 billion just for the West Branch and total amount estimated in US\$ 8.4 billion. Second the extension-approximately $170 \mathrm{~km}$ of two pairs of triple lanes for the entire beltway. Third, its role in public policy as an investment designed on the basis of robust studies and analyses that took into account environmental concerns and the results of public hearings.

A priori impact evaluation conducted by the state government shows that the West Branch of Rodoanel would have insignificant effects on residential land value and on commuting time to São Paulo downtown. This would happen because the purpose of Rodoanel is to re-direct cargo traffic passing-through the SPMA. So it would not produce accessibility gains for daily commuters from home to work. But considering the traffic problems of São Paulo and the peak-hour congestion, the West Branch of Rodoanel can be used as an alternative commuting 
route. In that case, its effects on accessibility will be higher than estimated in the government evaluation.

Thus, following urban economic theory, the accessibility improvement caused by Rodoanel will be reflected in higher land prices. One way to deal with higher land values is to increase the density for new residential developments.

The paper is divided into three sections. Following this introduction, a first section describes the main characteristics of the Rodoanel beltway. A second section discusses the hedonic price approach to land use and housing analysis. A third section evaluates the impacts of Rodoanel announcement and construction on land prices. The concluding remarks indicate some of the policy implications of the analysis.

\section{Rodoanel History}

The idea of a beltway around São Paulo is not a new one. Since the fifties there have been projects and initial developments which were partially executed. The marginal avenues along the Pinheiros and Tietê rivers were components of two previous beltway projects.

The first beltway was planned in the thirties ${ }^{1}$ and deployed in the sixties to surround the inner area between the rivers Pinheiros and Tietê which are the main water courses of São Paulo. That area consists of downtown and the principal neighborhoods where services and commerce are located. Nowadays that area corresponds to the "expanded center" and resembles the idea of a Central Business District.

The second beltway was planned in seventies as an extension of the first one. The edges of such area interfaced with industrial neighborhoods, but not completely. The idea of a third beltway with a far eastern new border called 'Jacú-Pêssego Avenue' has been attempted but was never completely built.

The traffic jams in São Paulo continued to intensify over the years in spite of the road investments. Almost 40 percent of the total cargo transported by trucks in Brazil passes-

\footnotetext{
${ }^{1}$ See Prestes Maia (1930) for the original plan.
} 
through the SPMA. At the same time there are land use policies which affect mobility patterns. To address some of these issues a new beltway project has been developed in the late eighties and beginning of nineties and that is the origin of the 'Rodoanel Metropolitano.'

The announcement of Rodoanel was made in January 1995. Mario Covas was then state governor, elected in November 1994. As soon as Covas took office he decided to take up the new beltway project and start its construction. The necessary impact studies were carried out covering all technical, environmental and legal aspects, as well as financial arrangements. The timeline of Rodoanel West Section and the project milestone events are shown in Figure 1.

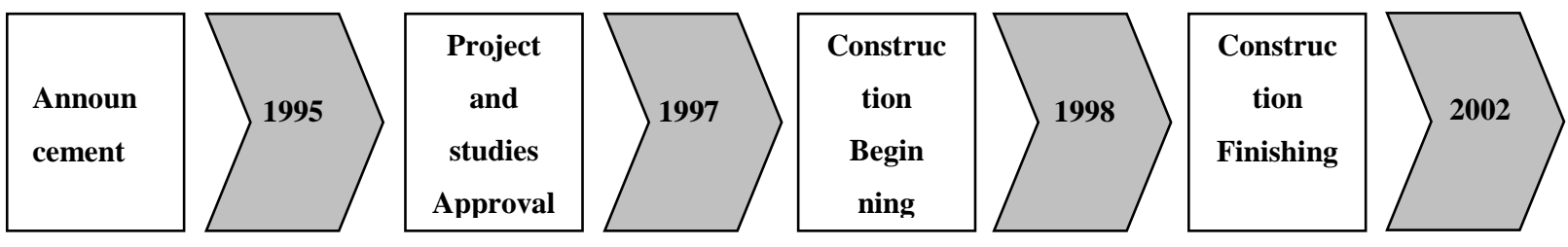

Figure 1 - Rodoanel West Section Timeline ${ }^{2}$

During project preparation, the main concern was the north section. The original route planned would cross the Environmental Protection Area of Serra da Cantareira, which is one of the main water sources for the SPMA (see the green area at the north in Figure 2).

Finally approval was granted for a new planned route in the northern area that avoided any crossings through the Environmental Protection Area of Serra da Cantareira. The strategy to implement the Rodoanel consisted in dividing its construction into four phases-each of them a section. The construction would begin by the western section which was the cheapest and the easiest. The South branch started on 2008 and was recently delivered. The Sao Paulo State is starting the process to build the third branch on the east but it will not resume before the new governor is elected.

\footnotetext{
${ }^{2}$ Source: Secretaria de Estado dos Transportes de São Paulo.
} 


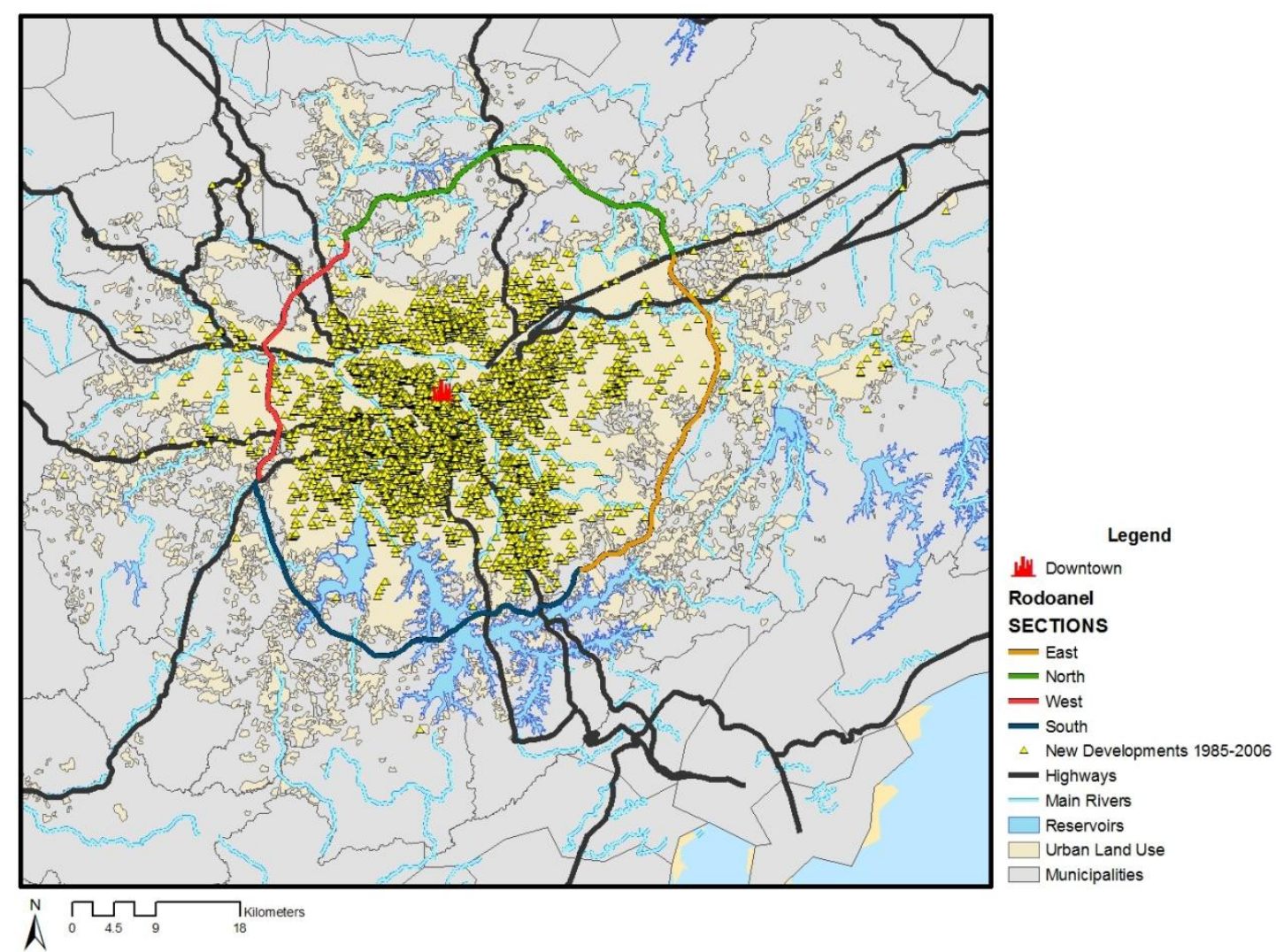

Figure 2 - Rodoanel Route (west section detached in red color) ${ }^{3}$

We test hypotheses related to two major events: the announcement and the construction of Rodoanel West Section. According to Boarnet and Chalermpong (2001) whose study evaluates new toll roads in Orange County, California, it is important to consider some threshold years and evaluate them because the value of the roads would not be fully capitalized in the announcement or at the beginning of the construction. He notes:

"Even with some foresight on the part of home buyers, we expected that the market assessment of the likelihood that the roads would be built would rise over the early years of our data (...).” (Boarnet \& Chalermpong 2001, pp.581)

\footnotetext{
${ }^{3}$ Source: Secretaria de Estado dos Transportes de São Paulo.
} 


\section{Hedonic Price Models and Land Use}

Hedonic price models have been regularly used in applied studies since the fifties, although they were formally developed in forties (Bartik, 1987). A hedonic price model refers to the demand for a good which encompasses several attributes. Therefore according to Lancaster (1966) the consumer does not buy a single good, but a bundle of different characteristics. Durable goods such as cars or appliances are typical examples. Houses also can be seen as a hedonic good because consumers buy simultaneously location, dimension, and quantity of bedrooms, bathrooms and other characteristics.

Rosen (1974) affirms that consumer's utility is obtained by the attributes of the commodity, not by the commodity itself. As a consequence any $\operatorname{good} z$ is expressed as a coordinator vector $z=\left(z_{1}, z_{2}, \ldots, z_{n}\right)$ of its $k$ characteristics. For this reason a hedonic price model is $p(z)=f\left(z_{1}\right.$, $\left.z_{2}, \ldots, z_{n}\right)$. A simple hedonic price equation is:

$$
p(z)=\beta_{0}+\sum_{k=1}^{K} \beta_{k} z_{k}
$$

Where each attribute $z_{k}$ has a marginal $\beta_{k}$ impact over $p(z)$, i.e., the marginal price of the characteristic or its implicit value.

According to Bartik (1987) the hedonic price function gives information about the consumer's marginal bid for an attribute in a market equilibrium situation. Thus each attribute's bid equals its marginal price. Therefore the hedonic equation is a reduced form of demand and supply simultaneous interaction system of equations.

Epple (1987) and Bartik (1987) point out specification problems due to implicit markets for the characteristics. Endogenous estimation and biased coefficients may come about if supply is not perfect inelastic or if there are unobservable preferences from households. 


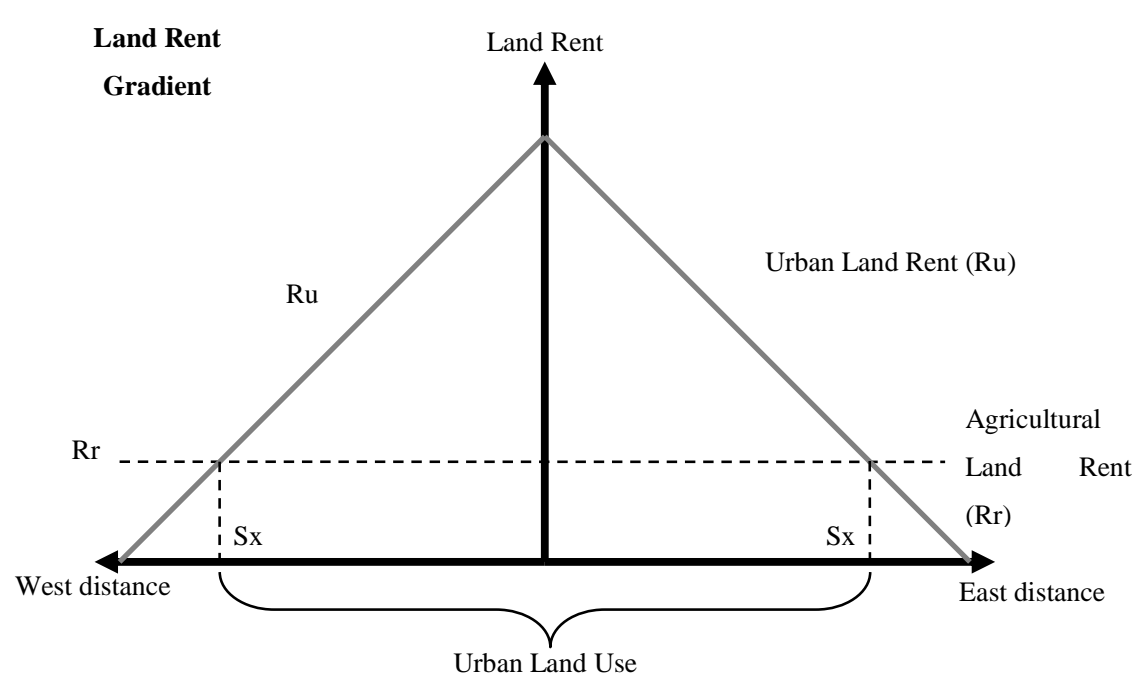

Figure 3 - Land Rent Gradient in a Linear City

One of the attributes of houses is distance from the CBD. This characteristic refers to land use and consequently to land price. Alonso (1960) shows the trade-off between land price and distance from CBD. This trade-off is due to transport costs, which are increasing to distance as represented in Figure 3 for a linear city model.

On the other hand there are negative externalities associated to the new infrastructure. As pointed out by Bouarnet and Chalermpong (2001), the proximity to the lanes (around 500 meters) can bring down house prices. The cause is the noise and air pollution due to the traffic.

So there are two driving forces interacting: accessibility and negative externality. The first helps to increase land prices and the second helps to decrease them. A priori we do not know which one is greater and where each predominates (around the beltway). 


\section{Data}

Land prices are not systematic available in datasets. One must look primary for information from field work. One way to deal with this problem is estimate land prices indirectly from house prices. In order to do that we follow Biderman (2001) whose study was the pioneer in using Embraesp (Empresa Brasileira de Estudos Patrimoniais) residential sales database for academic purposes.

Embraesp data cover the SPMA since 1985 and register the asking price only of new residential developments. So these data are not appropriate to evaluate repeated sales as is the usual practice in empirical housing market studies in the US. From 1985 to 2006 there are 10,367 observations in the Embraesp database. 9,460 of them could be geocoded, of which 9,093 have information about the area of the land parcel. It is not a statistical sample stricto sensu but contains all formal publicly-announced new developments. Thus it can be representative for some inferences about population. As a consequence our analysis of Rodoanel impacts does not take into account informal markets or commercial developments or re-sales. The Embraesp database contains dwelling-specific information (useful area, quantity of bedrooms and bathrooms etc.).

We incorporate the information on location-specific aspects using block data from the 2000 Census made available by CEM (Centro de Estudos da Metrópole) from CEBRAP (Centro Brasileiro de Análise e Planejamento). Cheshire and Sheppard (1995, pp. 248) suggest that 'if location-specific characteristics of housing are appropriately measured monocentric models can perform well.' So each new residential sale was spatially joined to its 2000 Census block attributes. The SPMA has more than 17,000 census blocks, each of them with about 400 dwellings units.

We also associated each residential unit with its Census 1991 sector. The purpose of doing so is to get the average income information from the heads of households in the sector. Further we explain the need for this information. 


\section{Hypotheses}

Assuming the monocentric shaped city and the gradient land price according to Alonso (1960), the main hypothesis we test is that Rodoanel West caused increases in land price on the west side of its ramps (Figure 4 - diagram on left). In spite of Rodoanel be focused on cargo transportation, we suspect that its lanes can be adopted for commuting purpose as the traffic jams in SPMA have been increasing and new routes are always looked for.

Conversely, proximity to the lanes may result in negative effects such as noise and air pollution due to traffic. These impacts tend to decrease the land price (Figure 4 - diagram on right).
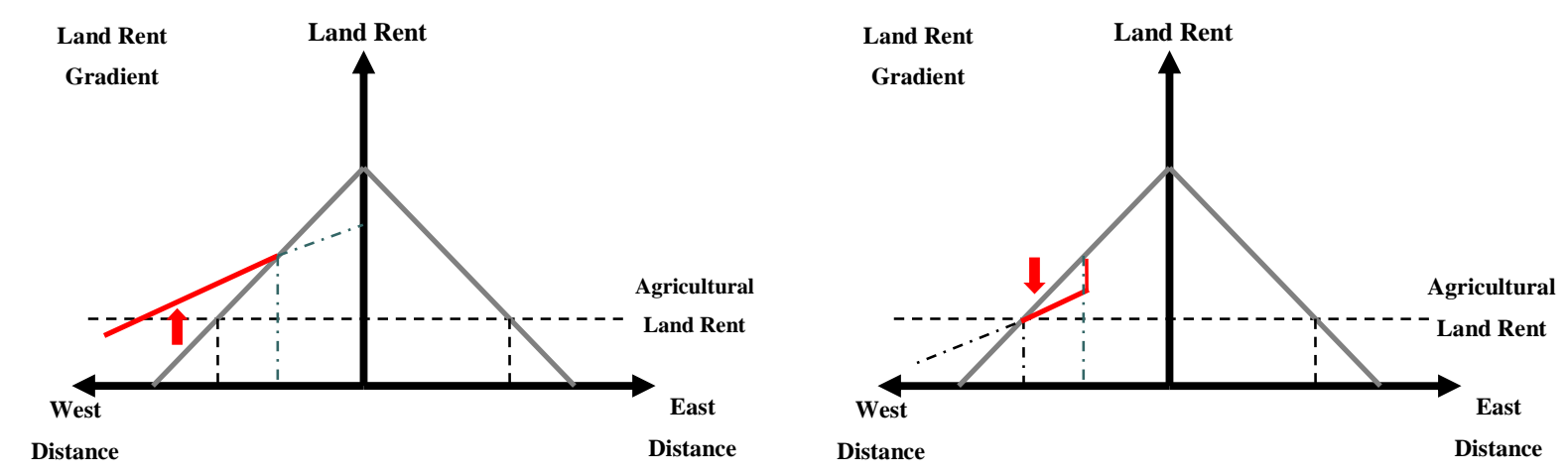

Figure 4 - Expected Effects on Land Prices after Rodoanel West Section Deployment

In summary, there are two types of effects that are not necessary exclusive: accessibility and negative externalities. We can state the hypothesis in three parts:

(1) Increasing land prices on the 'outside' of the beltway (e.g. accessibility effect predominates)

$$
\begin{aligned}
& H_{0}: \Delta p_{i j}>0 \\
& H_{1}: \Delta p_{i j} \leq 0
\end{aligned}
$$

(2) Decreasing land prices on the vicinity of the beltway's lanes (e.g. negative externalities predominate) 


$$
\begin{aligned}
& H_{0}: \Delta p_{i j}<0 \\
& H_{1}: \Delta p_{i j} \geq 0
\end{aligned}
$$

(3) No changes on land prices on the 'inside' of the beltway (e.g. none of the effects predominate)

$$
\begin{aligned}
& H_{0}: \Delta p_{i j}=0 \\
& H_{1}: \Delta p_{i j} \neq 0
\end{aligned}
$$

(Where $p_{i, j}$ is the residential land price for a dwelling unit $i$ located in zone $j$ )

If our hypothesis is confirmed it will allow us to conclude that those who live outbound of the beltway have an improvement in accessibility, while those who live near the lanes suffer negative effects from traffic, and those who live inbound experience no effect. The consequences for public policy will be several as we discuss further.

\section{Research Strategy}

We do not want to explore specific situations of Rodoanel West Section such as informal settlements accessibilities or conflicts. We would like to find the average effects of the new highway on land prices related to its announcement and to its construction. So we adopt the traditional econometric methodology for hedonic price estimation.

The first step is to get information about land prices, which is the dependent variable here. Embraesp dataset covers the asking prices of new residential properties, i.e. combines the value of the land and the building in the property asking price. A possible way to obtain land prices is by dividing the asking price of the housing unit(s) by the area of the land parcel area of the parcel where the unit(s) is build.

$$
\frac{\text { Land Price }}{\text { squaremeters }}=\frac{\text { valueof then ew development }}{\text { parcel area in squaremeters }}
$$


It is important to mention that these values are in reais $(\mathrm{R} \$)$ deflated to the year of 2000 . Figure 5 shows the calculated land price histogram.

This measure is imperfect because we do not have the actual cost of production. The implication is the underline assumption of a constant capital-land relation which is a very strong assumption. As we know, the relation capital-land is increasing as we approach the CBD due to higher land prices. If we had the construction costs information the adequate land price could be computed as:

$\frac{\text { Land Price }}{\text { square meters }}=\left(\frac{\text { value of the new development }- \text { construction costs }}{\text { built area in square meters }}\right) \cdot \frac{\text { built area in square meters }}{\text { parcel area in square meters }}$

By using appropriate GIS software ${ }^{4}$ we calculate the minimum straight-line distance from each new residential unit offered for sale to the downtown center. Such measure is very important, as pointed out by Cheshire and Sheppard (1995), because it brings the urban rent theory approach to the analysis. The theory suggests a trade-off between land price and distance from CBD (e.g. a trade-off between accessibility and transport costs).

We also calculate the minimum straight-line distance from each new residential unit offered for sale to the Rodoanel West Section's lanes and ramps. This allows us to define buffers for the area of influence of the road and thus the treatment group (see Figure 5).

\footnotetext{
${ }^{4}$ ESRI ArcGIS 9.3 ${ }^{\mathrm{TM}}$.
} 


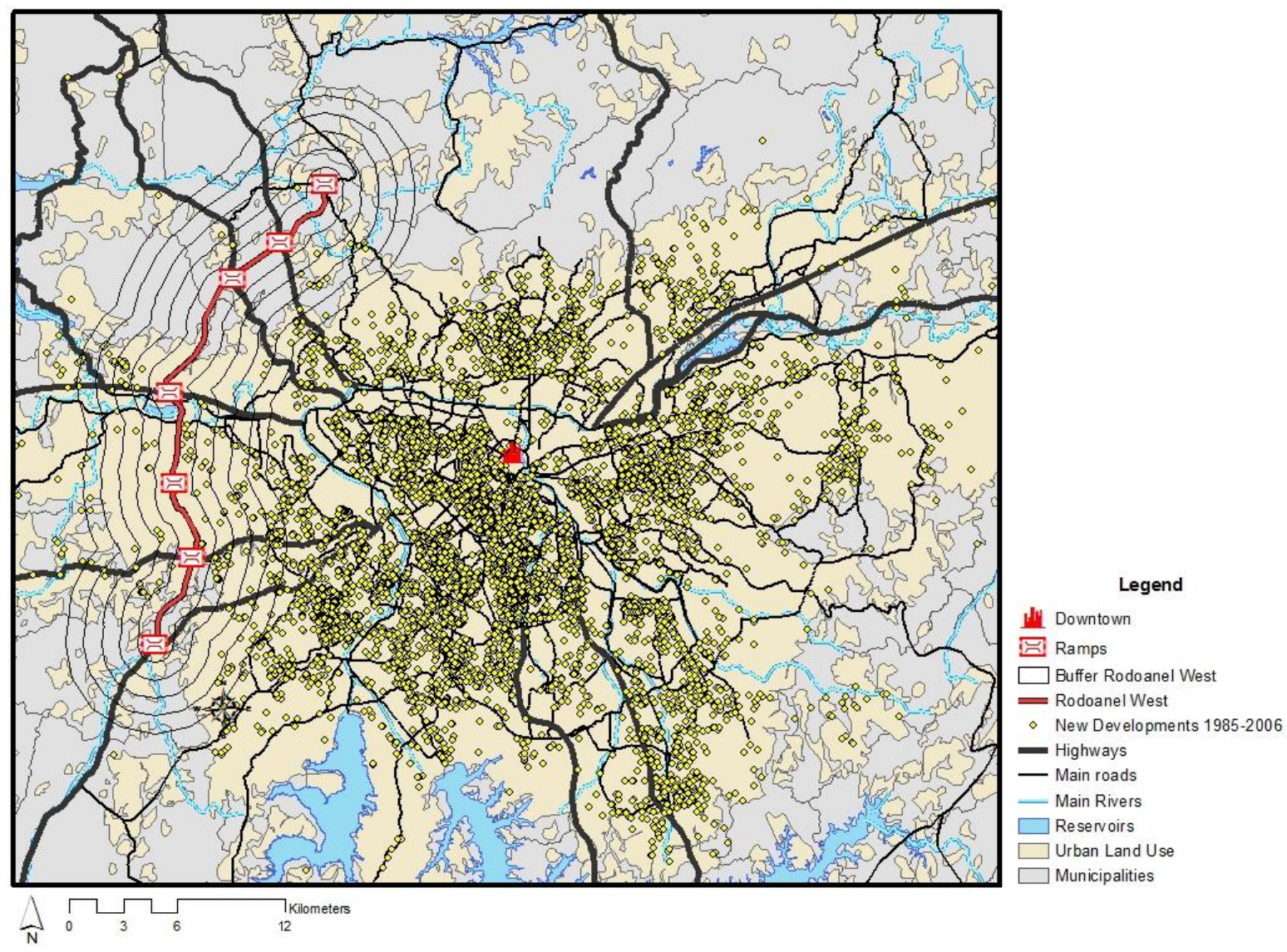

Figure 5 - New residential Developments (1985-2006) and Rodoanel West Section (track, ramps and buffers) ${ }^{5}$

So we can apply difference-in-differences ('dif-in-dif') technique in order to estimate the impacts caused by Rodoanel West Section. According to Stock and Watson (2003), a basic dif-in-dif specification is:

$$
\Delta Y_{i}=\beta_{0}+\beta_{1} X_{i}+\mu_{i}
$$

Where $\Delta Y_{i}$ can be considered as the variation on prices for the land parcel $i, \mathrm{X}_{\mathrm{i}}$ is the binary variable that informs if the land parcel is surrounding Rodoanel's ramps and $\beta_{1}$ is the causal effect from the deployment of Rodoanel.

\footnotetext{
${ }^{5}$ Source: Embraesp and Centre of Studies of Public Sector Politics and Economics at Getulio Vargas Foundation (CEPESP/FGV).
} 
More specifically we are looking land parcels in the site A affected by Rodoanel. If there is a site B that has not been crossed by Rodoanel, we can use it as a control group to compare the changes between A and B between the two periods (before and after its deployment). So we run the regression:

$$
\Delta Y_{i}=\beta_{0}+\beta_{1} T_{i}+\beta_{2} S A_{i}+\beta_{3}\left(T * S A_{i}\right)+\mu_{i}
$$

Where $Y$ is the price of land parcels in each site in each period. $T$ is a time (period) dummy, $S A$ is a state dummy for site $A$, and $T^{*} S A$ is the interaction of the period dummy and the site A dummy. Box 1 displays the hypothetical percentage variation on prices of land parcels in each state and time period and Box 2 explains what each coefficient in the regression represents.

\section{Box 1 - Hypothetical percentage variation on the prices of land parcels}

\begin{tabular}{lccc}
\hline & $\begin{array}{c}\text { Site A } \\
\text { (surrounding Rodoanel's } \\
\text { ramps) }\end{array}$ & $\begin{array}{l}\text { Site B } \\
\text { (not surrounding } \\
\text { ramps) }\end{array}$ & Rodoanel's \\
\hline $\begin{array}{l}\text { Period 1 (before the deployment } \\
\text { of Rodoanel) }\end{array}$ & $\mathrm{b}$ & $\mathrm{a}$ \\
$\begin{array}{l}\text { Period 2 (after the deployment of } \\
\text { Rodoanel) }\end{array}$ & $\mathrm{d}$ & $\mathrm{c}$ \\
\hline
\end{tabular}

Box 2 - Calculation and interpretation of regression coefficients

\begin{tabular}{llll}
\hline Coefficient & Calculation & Interpretation \\
\hline$\beta_{0}$ & $\mathrm{a}$ & $\mathrm{c}-\mathrm{a}$ & $\begin{array}{l}\text { Baseline average } \\
\text { Time trend in the control } \\
\text { group }\end{array}$ \\
& $\beta_{2}$ & $\mathrm{~b}-\mathrm{a}$ & $\begin{array}{l}\text { Differences between the two } \\
\text { sites in period 1 (before the } \\
\text { deployment of Rodoanel) }\end{array}$ \\
& $\beta_{3}$ & $(\mathrm{~d}-\mathrm{b})-(\mathrm{c}-\mathrm{a})$ & $\begin{array}{l}\text { Difference in the changes } \\
\text { over time, e.g. the 'true' } \\
\text { impact of Rodoanel. }\end{array}$ \\
\hline
\end{tabular}

We defined several treatment groups according to the interaction of site specific and period specific variables. Following Figure 1, the time specific variables marks the three general stages for the deployment of a transport infrastructure: planning, construction and operation. 
Each period comprehends a dummy variable which assumes ' 1 ' during the respective stage and ' 0 ' otherwise.

The site specific variables are divided into four groups of dummies. The first group is formed by residential units offered for sale located up to 2,500 meters from Rodoanel's ramps outbound. The second group is obtained in the same fashion but inbound. The third group captures the residential units offered for sale located beyond 2,500 meters from Rodoanel's ramps outbound. The fourth site specific group stands for the same range of distance from Rodoanel's ramps as the previous but inbound till 5,000 meters.

After matching addresses by condominiums and filtering out inappropriate data (as 'missing values') we are left with 7,392 new dwelling units from 1985 to 2006 with complete range of information. Table 1 summarizes the distribution of observations by interacting site specific and location specific variables. They are the treatment groups and their coefficients represent the net effect of Rodoanel West Section.

Table 1 - Treatment Groups (number of observations)

\begin{tabular}{|c|c|c|c|}
\hline $\begin{array}{l}\text { Interactive } \\
\text { (site*period) }\end{array}$ & $\begin{array}{l}\text { Announcement and } \\
\text { Planning }\end{array}$ & Construction & $\begin{array}{c}\text { Delivery and } \\
\text { Operation }\end{array}$ \\
\hline $\begin{array}{l}\text { Group } 1 \\
\text { (outbound till 2500m) }\end{array}$ & 0 & 2 & 8 \\
\hline $\begin{array}{l}\text { Group } 2 \\
\text { (inbound 2500m) }\end{array}$ & 8 & 5 & 14 \\
\hline $\begin{array}{l}\text { Group } 3 \\
\text { (outbound 2500m) }\end{array}$ & 0 & 4 & 42 \\
\hline $\begin{array}{l}\text { Group } 4 \\
(2500 \mathrm{~m}<\text { inbound }<5000 \mathrm{~m})\end{array}$ & 12 & 7 & 32 \\
\hline
\end{tabular}

But we know there are others factors driving the prices that we must take them into account. Thus our estimator is a kind of dif-in-dif with additional regressors (hedonic price regression).

$$
\Delta Y_{i}=\beta_{0}+\beta_{1} T_{i}+\beta_{2} S A_{i}+\beta_{3}\left(T * S A_{i}\right)+\beta_{j} \sum_{j=4}^{k} W_{j i}+\mu_{i}
$$




\subsection{Hedonic Price Regression Analysis}

Following the methodology of Boarnet and Chalermpong (2001), Wilson and Frey (2007) and Gatzlaf and Smith (1993) we develop hedonic price regressions. ${ }^{6}$ However we take into account Cheshire and Sheppard (1995) suggestion that linear forms of the hedonic land price model may have non-normal errors. Therefore we adopt the log-form specification. In addition to support this choice, Figure 6 shows the histogram of the natural logarithm of land prices. The distribution of the logarithm of the prices seems to be closer to the log-normal distribution.

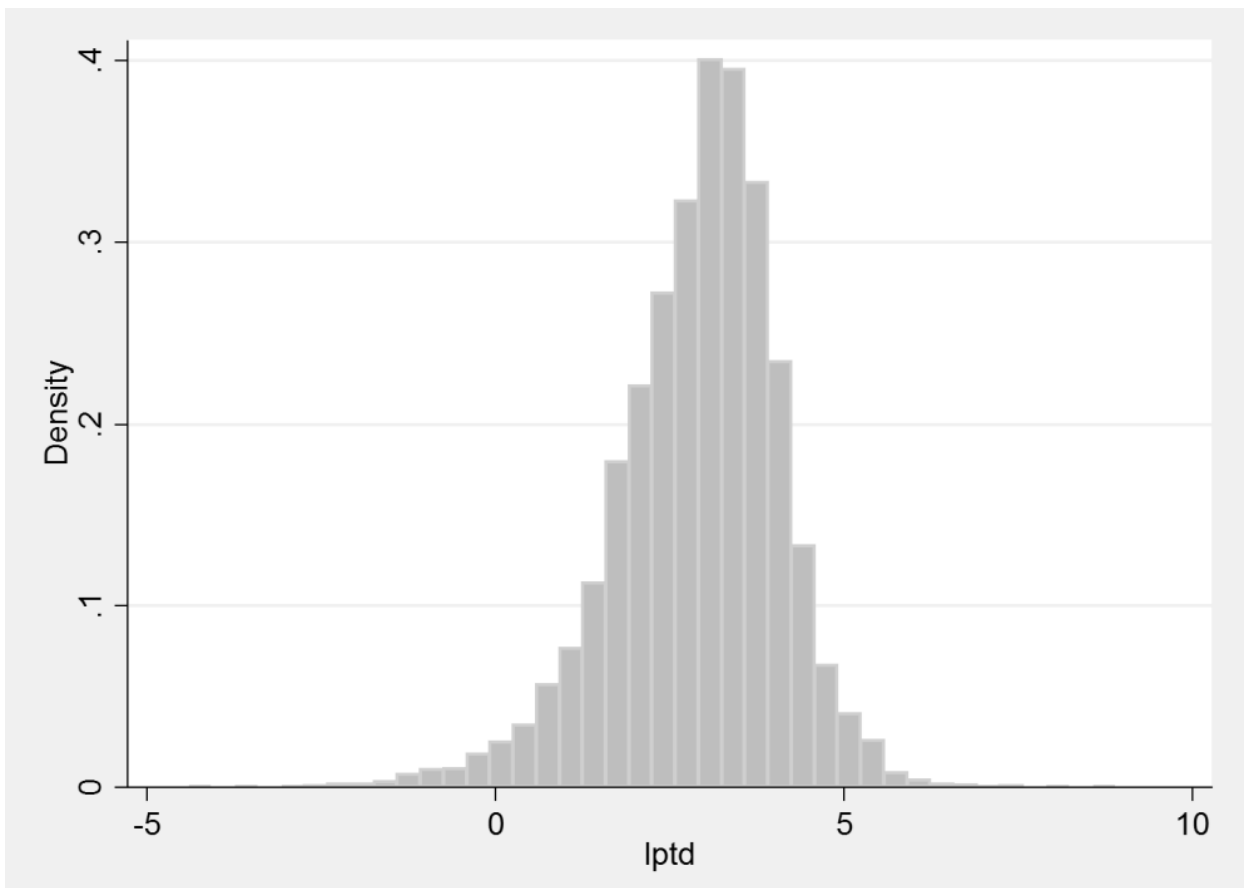

Figure 6 - Histogram of the Natural Log of Square Meter Price of Land - deflated values (1985-2006)

The model should consider the two groups of factors that drive the land prices as we calculated: dwelling-specific and location-specific factors. Thus the model general specification $^{7}$ is:

\footnotetext{
${ }^{6} \mathrm{We}$ ran the regressions in Stata $10 \mathrm{SE}^{\mathrm{TM}}$ software.

${ }^{7}$ Following Bartik (1987) and Cheshire and Sheppard (1995).
} 
$\ln (p)=\beta_{0}+$ Dwelling_Unit' $\beta+$ Site' $\gamma+\partial_{1}$ Announcemat $+\partial_{2}$ Construction $+\partial_{3}$ Delivery +

$+\partial_{4}$ Group $1+\partial_{5}$ Group $2+\partial_{6}$ Group $3+\partial_{7}$ Group4 +

$+\partial_{8}$ Announce mat.Group1 $+\partial_{9}$ Announcem at.Group2 +

$+\partial_{10}$ Announcemat.Group3 $+\partial_{11}$ Announcemat.Group4 $+\partial_{12}$ Construction.Group1+

$+\partial_{13}$ Construction.Group2 $+\partial_{14}$ Construction.Group3 $+\partial_{15}$ Construction.Group4 +

$+\partial_{16}$ Delivery .Goup $1+\partial_{17}$ Delivery .Goup $2+\partial_{18}$ De livery .Group3 +

$+\partial_{19}$ Delivery.Goup $4+\varepsilon$

Where $p=$ new home sales asking price deflated to 2000 Reais, using the General Price Index (IGP-DI) for Brazil provided by the Getulio Vargas Foundation; Dwelling_Unit = vector of dwelling unit characteristics such as size (useful area), number of bedrooms, number of bathrooms, number of parking spaces etc.; and Site = vector of site attributes such as water system and sewage coverage, head of household average monthly income, dummy for home located in the municipality of São Paulo, straight-line distance from São Paulo downtown.

One option would be to adopt a panel data regression (as 'fixed effects' methodology). Unfortunately the micro level data are not a true panel. Each new development appears once in the sample (as noted earlier, it is not a repeated-sale database). Even if we aggregate the units for a local average it will be an unbalanced panel, with less degree of freedom. For this reason the use of pooled data and dummies seem to be more appropriate.

Take into account that we want to evaluate the effects of the Rodoanel on surrounding parcels, we have a quasi-experiment. The model that we adopt to estimate the impact of the Rodoanel on the variation of prices from surrounding parcels is a type of dif-in-dif regression. Note that the dependent variable $\ln \left(p_{i}\right)$ is equivalent to $\Delta p_{i} / p_{i}$.

It is important to mention how the average monthly income of the head of household is computed. For all residential development launched before the announcement of Rodoanel we adopt the values from the 1991 Census. Otherwise we adopt the values from the 2000 Census. Therefore we take into account changes in income that could drive the demand for dwelling units which may affect their prices. 


\section{Results}

We run several regressions changing the control group (see Appendix). In the first regression we considered the full sample and decomposed each time-period described on Figure 1 and each group described on Table 1. The second and the third regressions collapsed the time and site specific dummies in order to look for more general effects. Regressions 4 to 6 constrain the sample to housing located at the same distance from the CBD as the treatment groups.

Almost all control variables are significant at 1 percent and in general have the expected sign. The variables of interest are the interaction between site location (the groups) and the timing. For instance, the interaction between the construction period dummy and group 1 dummy would give us the (counter-factual) impact of the beltway construction on land prices within $2.5 \mathrm{~km}$ outbound of the beltway.

The impact of the beltway on land prices is different according to the stage of deployment. The announcement stage brings some positive expectations about benefits, but it is not clear whether they are going to be real. Boarnet and Chalermpong (2001) point out that new highway investments cast doubt on economic agents. Those kinds of investments require huge amounts of resources and face litigations and environmental barriers. Therefore the full values of the roads are not capitalized into land prices until works are completed. In the specific case of Rodoanel West Section the discredit was expressed in non-significant changes in prices. Later on agents can better anticipate benefits and cost.

Construction, in contrast to announcement, shows that legal and technical barriers were overcome. As a result discredit vanishes. So there is one significant effect when construction turns out to be true. Residential developments located outbound of the lanes and near the ramps face a 133 percent increase in land prices. On the other hand other locations have negative but non-significant decrease in prices, except the group that is beyond $2.5 \mathrm{~km}$ outbound of the road, which have a significant and negative impact. 
Table 2 - Estimated coefficients and standard errors for selected independent variables from general regression with full sample ${ }^{8}$

\begin{tabular}{lccc}
\hline 'Causal' Effects & $\begin{array}{c}\text { Announcement and } \\
\text { Planning }\end{array}$ & Construction & Delivery and Operation \\
\hline Group 1 & - & $1.3266^{* * *}$ & 0.5434 \\
(outbound till 2500 m) & - & $(0.1498)$ & $(0.4753)$ \\
\hline Group 2 & -0.1043 & -1.0506 & -0.3324 \\
(inbound till 2500 m) & $(0.3176)$ & $(0.6404)$ & $(0.2179)$ \\
\hline Group 3 & 0.3735 & $-0.8552^{* *}$ & $-0.6044^{* * *}$ \\
(outbound beyond 2500 m) & $(0.3193)$ & $(0.3855)$ & $(0.2073)$ \\
\hline Group 4 & 0.3246 & 0.0889 & $-0.3397^{*}$ \\
$(2500$ m<inbound $<5000 \mathrm{~m})$ & $(0.2154)$ & $(0.4594)$ & $(0.1957)$ \\
\hline
\end{tabular}

The negative impact on Group 3 is the only result that does not changes after delivery and operation. The lack of significance of the delivery suggests that capitalization have happened mainly during construction. In general, the effects for those who live inbound (e.g. closer to the CBD) are not significant. Since it does not make a lot of sense the negative sign we believe that we may be confounding the impacts on areas beyond $2.5 \mathrm{~km}$ with some other event that we are not able to control.

We first collapse the time variable into one major event: the physical presence of the lanes (construction and delivery). This specification reduces the time specific dummies to the simplest possible form. It assumes ' 0 ' for all periods before construction and ' 1 'after it. The results follow the same general patterns of the decomposed regression. We then omit groups 3 and 4 and concentrate the analysis on Groups 1 and 2.

Table 3 shows the results. Now we are analyzing only the land located near the ramps to Rodoanel outbound and inbound. The results are compatible with the previous ones. Rodoanel West brings accessibility benefits for those who live on the outbound of the lanes but not for those who live on the inbound side. However, the positive effects are non-significant suggesting that the net impact on land prices might have been negative.

\footnotetext{
${ }^{8}$ Robust standard errors below coefficients. * $p<0.10, * * p<0.05, * * * p<0.01$.
} 
Table 3 - Impact of the Rodoanel Construction on Land Price in the Inbound and Outbound Surrounding Areas - Full Sample ${ }^{9}$

\begin{tabular}{lc}
\hline 'Causal' Effects & Construction and Operation \\
\hline Group 1 & 0.6666 \\
(outbound till 2500 m) & $(0.4146)$ \\
\hline Group 2 & $-0.4461^{*}$ \\
(inbound 2500 m) & $(0.2400)$ \\
\hline
\end{tabular}

We then restrict the geography in order to compare the treatment group with more similar areas. We first impose that the site cannot be in the vicinity of any relevant transportation investment (but the Rodoanel, evidently) built from 1986 to 2006. Thus the number of observations dropped to 5,833 cases. In order to do that, we first identify and segregate other relevant transports investments made during the period. There were several investments but the most important are the following:

- The extended subway Green Line which reached Sumaré and Vila Madalena neighborhoods;

- The new subway Purple Line in the southern of the city of São Paulo;

- The extension of Faria Lima Avenue and the connection to Hélio Pelegrino Avenue;

- The initial new lanes for 'Fura-Fila' Bus Rapid Transit (BRT);

- The new Águas Espraiadas Avenue;

- The interconnection of Bandeirantes Avenue and the ramp to Anchieta Highway ('Complexo Maria Maluf') - an improvement on the first beltway;

- The extension of Jacú-Pêssego Avenue - an improvement on the third projected (and uncompleted) beltway.

\footnotetext{
${ }^{9}$ Robust standard errors below coefficients. $* p<0.10, * * p<0.05, * * * p<0.01$.
} 


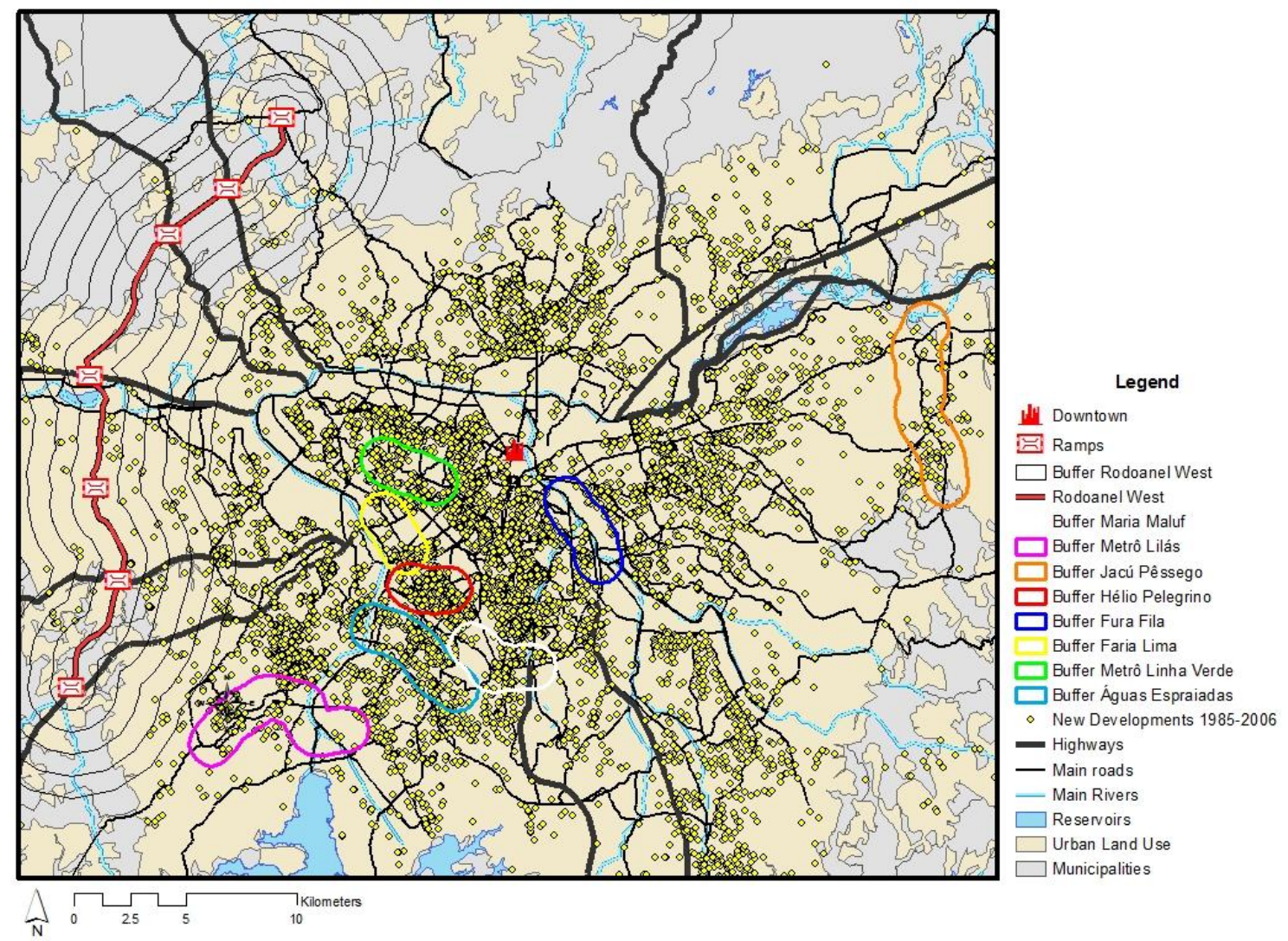

Figure 7 - Relevant Transport Investments (buffers), New residential Developments (1985-2006) and Rodoanel West Section (track, ramps and buffers) ${ }^{10}$

Then we locate these interventions using GIS software. For each intervention we create a buffer of $1.0 \mathrm{~km}$ around its track and dropped all new residential developments inside these buffers. The idea is that these cases cannot be considered as a control group since those households have indeed increased their accessibility in the period. The ideal control group would be households that have their accessibility not significantly affected in the period. The interesting result is that now the impact on the outbound sites is significant and it is still positive. The impact on the inbound neighborhood of the road is still significant and negative. These results are confirming the asymmetrical impact of the highway.

\footnotetext{
${ }^{10}$ Source: Embraesp and Centre of Studies of Public Sector Politics and Economics at Getulio Vargas Foundation (CEPESP/FGV).
} 
Table 4 - Impact of the Rodoanel Construction on Land Price in the Inbound and Outbound Surrounding Areas - Sites With no Relevant Investment in Transport ${ }^{11}$

\begin{tabular}{lc}
\hline 'Causal' Effects & Construction and Operation \\
\hline Group 1 & $0.7217^{*}$ \\
(outbound till 2500 m) & $(0.4140)$ \\
\hline Group 2 & $-0.3998^{*}$ \\
(inbound till 2500 m) & $(0.2401)$ \\
\hline
\end{tabular}

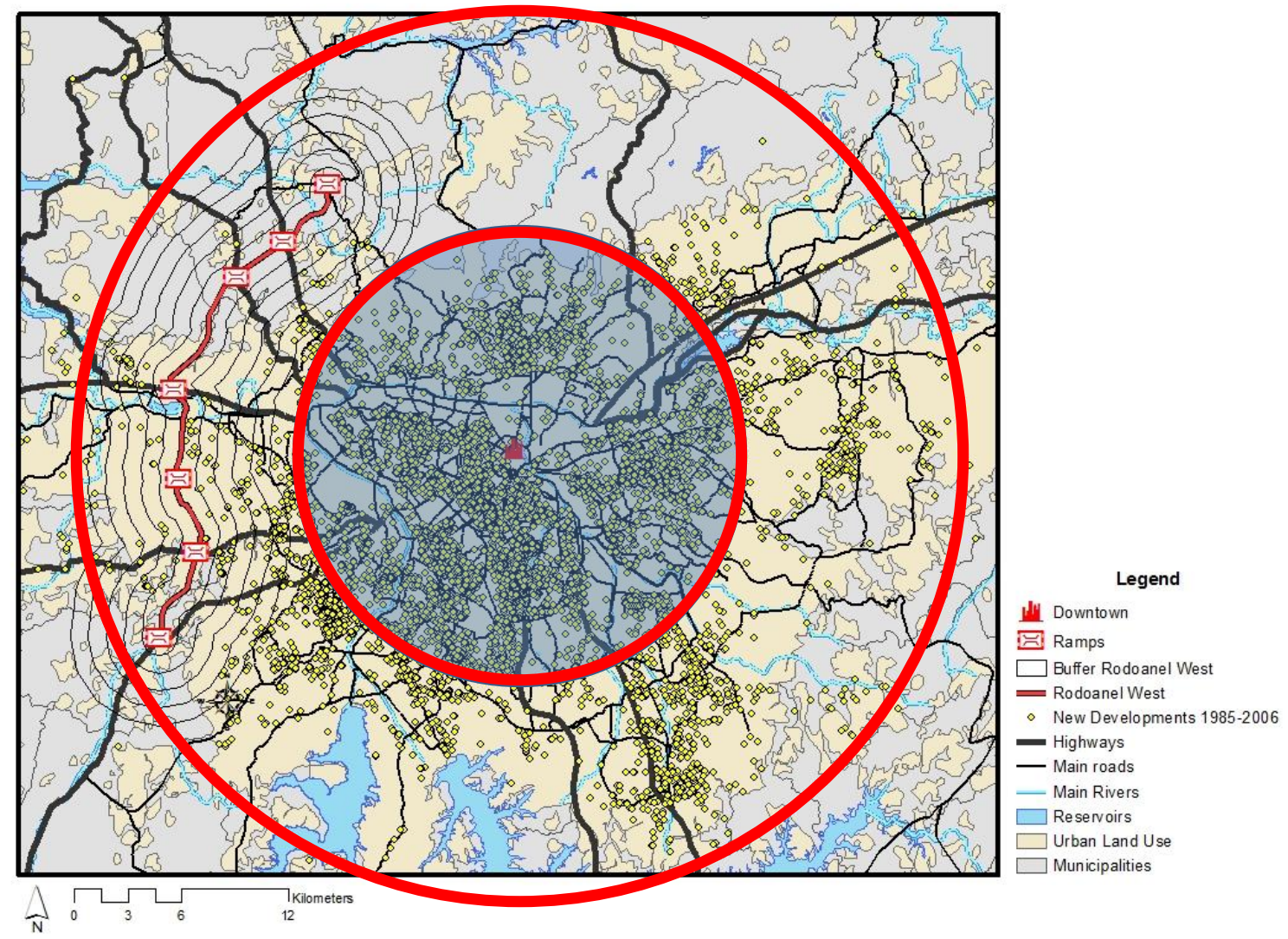

Figure 8 - Relevant Transport Investments (buffers), New residential Developments which distance from CDB is at least $15.5 \mathrm{~km}(\mathbf{1 9 8 5 - 2 0 0 6 )}$ and Rodoanel West Section (track, ramps and buffers) ${ }^{12}$

\footnotetext{
${ }^{11}$ Robust standard errors below coefficients. * $\mathrm{p}<0.10$, ** $\mathrm{p}<0.05$, *** $\mathrm{p}<0.01$.

${ }^{12}$ Source: Embraesp and Centre of Studies of Public Sector Politics and Economics at Getulio Vargas Foundation (CEPESP/FGV).
} 
We then restrict the sample of new developments for which distance from CDB is at least $15.5 \mathrm{~km}$ (see Figure 8). This threshold is the closest distance to the CBD from any development in the treatment group. If the rent gradient is changing over time, using the entire sample could imply that we are confounding the impact on the (whole) gradient with the impact of the road. Concentrating on the same distance from the CBD would allow to control for such possible pattern.

As we can see the impact of Rodoanel's is still significant for the prices of Groups 1. For Group 2 the impact are still positive but not significant.

Table 5 - Impact of the Rodoanel Construction on Land Price in the Inbound and Outbound Surrounding Areas - Sites with no Relevant Investment in Transport and more than $15.5 \mathrm{~km}$ far from the $\mathrm{CBD}^{13}$

\begin{tabular}{lc}
\hline 'Causal' Effects & Construction and Operation \\
\hline Group 1 & $0.9496^{* *}$ \\
(outbound till 2500 m) & $(0.4317)$ \\
\hline Group 2 & 0.3357 \\
(inbound till 2500 m) & $(0.2831)$ \\
\hline
\end{tabular}

Finally we drop from the analysis the new residential developments located up to $1 \mathrm{~km}$ from the lanes. This follows a similar procedure used by Boarnet and Chalermpong (2001) in order to deal with noise and air pollution externalities from the traffic. With this new restriction we end up with 493 observations.

As we can see the in Table 6, the impact of Rodoanel's operation is again positive on the prices of Groups 1 and 2, but it is significant just for the first one. The sign and significance are exactly the same found in the previous regression and the magnitude of the coefficients is very similar to the previous specification. Thus it seems that the eventual negative effects of being near the lanes are not stronger enough to overcome the benefits of accessibility.

\footnotetext{
${ }^{13}$ Robust standard errors below coefficients. $* \mathrm{p}<0.10, * * \mathrm{p}<0.05, * * * \mathrm{p}<0.01$.
} 
Table 6 - Impact of the Rodoanel Construction on Land Price in its Inbound and Outbound Surrounding Areas - Sites with no Relevant Investment in Transport, more than $15.5 \mathrm{~km}$ far from the CBD and more than $1 \mathrm{~km}$ far from the Rodoanel ${ }^{14}$

\begin{tabular}{lc}
\hline 'Causal' Effects & Construction and Operation \\
\hline Group 1 & $0.9084^{*}$ \\
(outbound till 2500 m) & $(0.4701)$ \\
\hline Group 1 & 0.3177 \\
(outbound till 2500 m) & $(0.3578)$ \\
\hline
\end{tabular}

We summarize the statistically significant findings in Table 7 in order to bring about better and clear synthesis.

Table 7 - Variations on housing land parcels caused by Rodoanel West Section

\begin{tabular}{|c|c|c|c|c|c|}
\hline & $\begin{array}{l}\text { Compared to } \\
\text { the rest of the } \\
\text { land parcels of } \\
\text { SPMA }\end{array}$ & $\begin{array}{l}\text { Compared to } \\
\text { the rest of the } \\
\text { land parcels of } \\
\text { SPMA } \\
\text { (collapsing } \\
\text { time variables } \\
\text { into one major } \\
\text { event: } \\
\text { construction } \\
\text { and delivery) }\end{array}$ & $\begin{array}{l}\text { Compared to } \\
\text { sites with no } \\
\text { relevant } \\
\text { investment in } \\
\text { transport }\end{array}$ & $\begin{array}{l}\text { Compared to } \\
\text { sites with no } \\
\text { relevant } \\
\text { investment in } \\
\text { transport and } \\
\text { more than } \\
15.5 \mathrm{~km} \text { far } \\
\text { from the CBD }\end{array}$ & $\begin{array}{l}\text { Compared to } \\
\text { sites with no } \\
\text { relevant } \\
\text { investment in } \\
\text { transport, } \\
\text { more than } \\
15.5 \mathrm{~km} \text { far } \\
\text { from the CBD } \\
\text { and more than } \\
1 \mathrm{~km} \text { far from } \\
\text { the Rodoanel }\end{array}$ \\
\hline $\begin{array}{l}\text { Group 1 } \\
\text { (outbound till } \\
2500 \mathrm{~m} \text { ) }\end{array}$ & $\begin{array}{l}133 \% \text { during } \\
\text { construction }\end{array}$ & - & $\begin{array}{l}72 \% \text { during } \\
\text { deployment }\end{array}$ & $\begin{array}{l}95 \% \text { during } \\
\text { deployment }\end{array}$ & $\begin{array}{l}91 \% \text { during } \\
\text { deployment }\end{array}$ \\
\hline $\begin{array}{l}\text { Group } 2 \\
\text { (inbound till } \\
2500 \mathrm{~m} \text { ) }\end{array}$ & - & $\begin{array}{l}-45 \% \text { during } \\
\text { deployment }\end{array}$ & $\begin{array}{l}-40 \% \text { during } \\
\text { deployment }\end{array}$ & - & - \\
\hline
\end{tabular}

If we read the different estimations 'backwards' we will note the general nature of the asymmetrical effects of Rodoanel:

\footnotetext{
${ }^{14}$ Robust standard errors below coefficients. $* \mathrm{p}<0.10, * * \mathrm{p}<0.05, * * * \mathrm{p}<0.01$.
} 
1) Residential land parcels around the track of Rodoanel have negative or null price changes depending on the different sides from its lanes and the different distances from its ramps (when compared to more restricted comparison groups - e.g. similar characteristics but distant from any relevant transport intervention and/or equally distant from CBD).

2) The different periods of deployment have different effects on land prices. Rodoanel is a huge infrastructure project that took seven years from the announcement to the beginning of operations for its first section. If we do not take this into account we will misunderstand how Rodoanel has affected land prices.

3) Residential land parcels around the track of Rodoanel have negative or null or positive price changes depending on the different sides from its lanes and the different distances from its ramps (when compared to less restricted comparison groups).

In short, the results obtained by the econometric models show an asymmetric effect of Rodoanel on land prices. Let us take the last specification as the ultimate specification to be tested in order to discuss these results (see the last column on Table 7). Although the results corroborate the general hypothesis of asymmetry, there are some specific differences highlighted in Box 3.

\section{Box 3 - Expected versus Estimated Effects: conclusions $^{15}$}

\begin{tabular}{ll}
\hline \multicolumn{1}{c}{ Original Hypothesis } & \multicolumn{2}{c}{ Conclusion } \\
\hline $\begin{array}{l}\text { Increasing land prices on the 'outside' of the } \\
\text { beltway (e.g. accessibility effect predominates) }\end{array}$ & $\begin{array}{l}\text { The effects are significant and positive for } \\
\text { residential land parcels closer to the } \\
\text { Rodoanel's ramps*. }\end{array}$ \\
$\begin{array}{ll}\text { Decreasing land prices on the vicinity of the } \\
\text { beltway's lanes (e.g. negative externalities } \\
\text { predominate) }\end{array}$ & $\begin{array}{l}\text { The negative externality from closer proximity } \\
\text { seems to be not significant (at least for the new } \\
\text { residential developments). }\end{array}$ \\
$\begin{array}{l}\text { No changes on land prices inbound the beltway } \\
\text { (e.g. none of the effects predominate) }\end{array}$ & $\begin{array}{l}\text { The effects are not significant (statistically } \\
\text { null) for residential land parcels closer to } \\
\text { Rodoanel's ramps**. }\end{array}$ \\
\hline
\end{tabular}

\footnotetext{
$15 *$ For parcels which are located farther (beyond $2.5 \mathrm{~km}$ ) the effects are not significant (statistically null). ** For parcels which are located farther (between $2.5 \mathrm{~km}$ and $5 \mathrm{~km}$ ) the effects are negative and significant.
} 
Figure 9 shows a schematic representation of the result found: a kinked land rent gradient which is below the former land rent gradient for residential land parcels located on the right side of the ramps to the lanes and it is above the former land rent gradient for residential land parcels located up to $2.5 \mathrm{~km}$ on the left from the ramps to the lanes. The latter are those who really seem to obtain commuting benefits from the beltway. It should be noticed that there were no significant improvement in commuting alternatives (such as bus and commuter rail) along the west side of SPMA during the period evaluated.

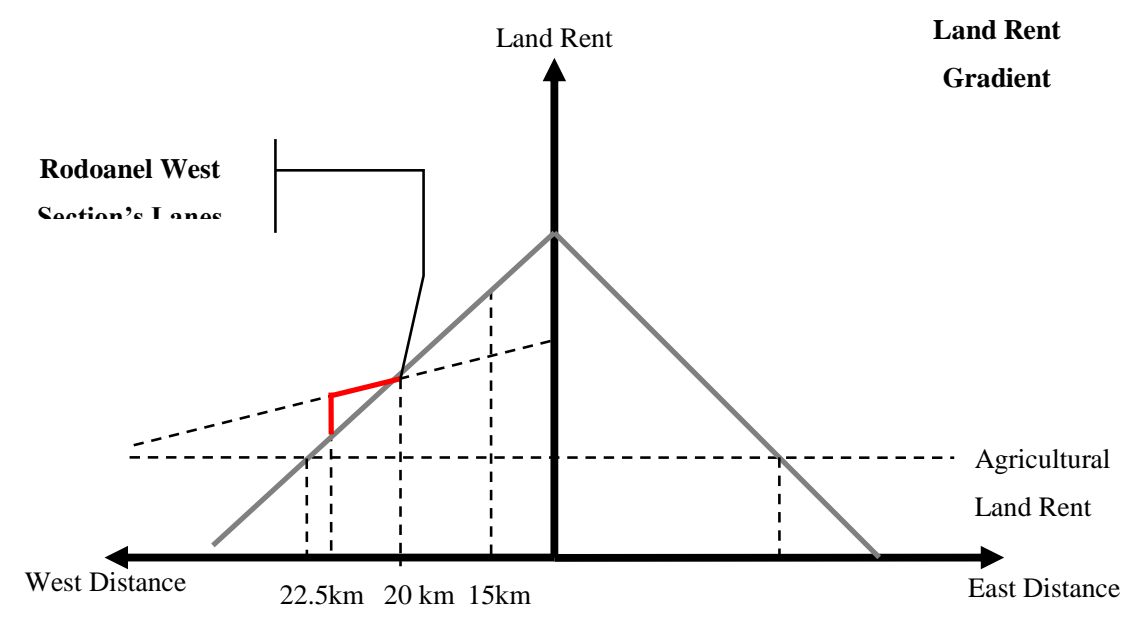

Figure 9 - Illustration of the Results from Hedonic Price Equation (last specification)

These short-run effects tend to vanish over the years as residential and commercial location decisions are made. Also the better level of commuting service brought by Rodoanel will tend to diminish as the demand for the beltway goes up. Whereas changes on density seem to be plausible around the new beltway, there is no reason to believe that it can have enough power to contribute to increasing urban sprawl.

These findings would suggest taxation possibilities for purposes of urban policy. The economic rent created by Rodoanel could be taxed to fund the next section of the beltway or to cover its operational expenses. On the other hand if a tax is levied, that could reduce any advantage for new residential developments located far from the CBD.

The problem is that property taxes in Brazil are the responsibility of municipalities and the Rodoanel investment is funded by the state and the national government. Moreover, the eventual capturing of the incremental land value through property tax and the corresponding 
increase in municipal tax revenue can only be realized by the municipalities on the west of the beltway since, as we have seen, parcels on the east side experienced a decline in land values. Consequently the municipality of São Paulo, located on the east side of the beltway, would face a decline in property tax revenues from parcels located near the beltway.

The appropriation for commuting use of a road designed for cargo traffic, as is the case of Rodoanel, and the potential rent generated by this behavior is reflected in the congestion observed near the intersections of the beltway with radial highways in the peak-hours. That is one of the reasons why São Paulo state government was motivated to implement tolls on the ramps to Rodoanel West Section in the beginning of 2009.

A broader implication of this analysis relates to regional and local policies and their effects. In a general Keynesian framework, new infrastructure investment always increases income by virtue of its multiplier effects. But if we look at the micro level, these effects do not always hold. There are redistributive gains and losses for different private agents located in the area of influence of the investment and also different effects for the municipalities involved. Although at the state and national levels the benefits are great, for some neighborhoods or municipalities the impact may be small or even negative. 


\section{Conclusion}

This paper shows the findings from a research about the impact of the West Section of the Rodoanel beltway on land prices. We evaluate road announcement, construction and delivery/operation events. The results of the econometric methods used show that there are significant and asymmetrical effects attributed to Rodoanel.

The Roadanel construction and delivery/operation increase land prices of parcels located closer to ramps on the west side of the track. The connection between the beltway and the radial highways may be providing new commuting routes to the São Paulo CBD.

For parcels located on the east side of the beltway, relatively far from the track (between 2.5 $\mathrm{km}$ and $5 \mathrm{~km}$ ), the effects of construction and delivery/operation have the opposite effect: these parcels face a decline in land prices.

These micro-level results must be computed and taken into account when considering the application of transportation finance with betterment levies and value capture policies, for welfare considerations and also for equity and political reasons. 


\section{References}

Alonso, W. (1960) Theory of urban land market. Papers and Proceedings of Regional Science Association, vol. 6, pp. 149-157.

Bartik, T. (1987) The estimation of demand parameters in hedonic price models. Journal of Political Economy, vol. 95, n. 11, pp. 81-88.

Becker, S. O. and Ishino, A. (2002) Estimation of average treatment effects based based on propensity score. The Stata Journal, vol. 2, n. 4, pp. 358-377.

Biderman, C. (2001) Forças de atração e expulsão na Grande São Paulo. Tese de Doutorado Apresentada ao Curso de Pós Graduação da EAESP/FGV. São Paulo: EAESP/FGV.

Bouarnet, M. G. and Charlermpong, S. (2001) New highways, house Prices, and urban development: a case study of toll roads in Orange County, CA. Housing Policy Debate, vol. 12, n. 3, pp. 575605 .

Chesschire, P. and Sheppard, S. (1995) On the price of land and the value of amenities. Economica, vol. 62 , n. 246, pp. 247-267.

Epple, D. (1987) Hedonic prices and implicit markets: estimating demand and supply functions for differentiated products. Journal of Political Economy, vol. 95, n. 11, pp. 59-80.

Gatzlaff, D. H. and Smith, M. T. (1993) The impact of Miami metrorail on the value of residences near station locations. Land Economics, vol. 69, n. 1, pp. 54-66.

Lanchaster, K. J. (1966) A new approach to consumer theory. Journal of Political Economy, vol. 74, n. 2, pp. 132-157.

Meyer, R., Grostein, M. and Biderman, C. (2004) São Paulo metrópole. São Paulo: EDUSP.

Prestes Maia, F. (1930) Plano de avenidas. São Paulo: Melhoramentos.

Rosen, S. (1974) Hedonic prices and implicit markets: product differentiation in pure competition, Journal of Political Economy, vol. 82, pp. 34-55.

Stock, J. H. and Watson, M. W. (2003) Introduction to econometrics. Addison Wesley.

Wheaton, W. (1977) Residential decentralization, land rents and the benefits of urban transportation. American Economic Review, vol. 67, n. 2, pp. 138-145.

Wilson, B. and Frew, J. (2007) Apartment rents and locations in Portland, Oregon: 1992-2002. Journal of Real Estate Research, vol. 29, n. 2, pp. 201-217. 


\section{Appendix}

Table 8 - Estimation results ${ }^{16}$

\begin{tabular}{|c|c|c|c|c|c|c|}
\hline Var. Dep.: Ln $(p)$ & $\begin{array}{c}\text { Regression } \\
1 \\
\end{array}$ & $\begin{array}{c}\text { Regression } \\
2 \\
\end{array}$ & $\begin{array}{c}\text { Regression } \\
\mathbf{3} \\
\end{array}$ & $\begin{array}{c}\text { Regression } \\
4 \\
\end{array}$ & $\begin{array}{c}\text { Regression } \\
5 \\
\end{array}$ & $\begin{array}{c}\text { Regression } \\
6 \\
\end{array}$ \\
\hline Constant & $\begin{array}{l}6.3157 * * * \\
(0.3160)\end{array}$ & $\begin{array}{l}6.3392 * * * \\
(0.3137)\end{array}$ & $\begin{array}{l}6.3676^{* * *} \\
(0.3145)\end{array}$ & $\begin{array}{l}6.2731 \text { *** } \\
(0.3448)\end{array}$ & $\begin{array}{l}14.4167 * * * \\
(2.6929)\end{array}$ & $\begin{array}{l}14.1118^{* * *} \\
(2.6959)\end{array}$ \\
\hline ln of useful area & $\begin{array}{l}-0.6868 * * * \\
(0.0468)\end{array}$ & $\begin{array}{l}-0.6356^{* * * *} \\
(0.0470)\end{array}$ & $\begin{array}{l}-0.6354 * * * \\
(0.0474)\end{array}$ & $\begin{array}{l}-0.6186^{* * *} \\
(0.0527)\end{array}$ & $\begin{array}{l}-0.8842 * * * \\
(0.2068)\end{array}$ & $\begin{array}{l}-0.8854 * * * \\
(0.2063)\end{array}$ \\
\hline \# of bedrooms & $\begin{array}{l}-0.0766 * * * \\
(0.0212)\end{array}$ & $\begin{array}{l}-0.0920 * * * \\
(0.0216)\end{array}$ & $\begin{array}{l}-0.0932 * * * \\
(0.0216)\end{array}$ & $\begin{array}{l}-0.0757 * * * \\
(0.0245)\end{array}$ & $\begin{array}{l}-0.0660 \\
(0.1062)\end{array}$ & $\begin{array}{l}-0.0933 \\
(0.1082)\end{array}$ \\
\hline \# of bathrooms & $\begin{array}{l}0.1537 * * * \\
(0.0225)\end{array}$ & $\begin{array}{l}0.1428 * * * \\
(0.0229)\end{array}$ & $\begin{array}{l}0.1436^{* * * *} \\
(0.0230)\end{array}$ & $\begin{array}{l}0.1189 * * * \\
(0.0257)\end{array}$ & $\begin{array}{l}0.3130^{* * * *} \\
(0.0922)\end{array}$ & $\begin{array}{l}0.3299 * * * \\
(0.0940)\end{array}$ \\
\hline \# of parking places & $\begin{array}{l}-0.0085 \\
(0.0195)\end{array}$ & $\begin{array}{l}-0.0264 \\
(0.0196)\end{array}$ & $\begin{array}{l}-0.0262 \\
(0.0197)\end{array}$ & $\begin{array}{l}-0.0332 \\
(0.0220)\end{array}$ & $\begin{array}{l}-0.1493^{*} \\
(0.0809)\end{array}$ & $\begin{array}{l}-0.1427^{*} \\
(0.0808)\end{array}$ \\
\hline \# of elevators & $\begin{array}{l}-0.0011 \\
(0.0058)\end{array}$ & $\begin{array}{l}-0.0031 \\
(0.0061)\end{array}$ & $\begin{array}{l}-0.0025 \\
(0.0061)\end{array}$ & $\begin{array}{l}-0.0008 \\
(0.0073)\end{array}$ & $\begin{array}{l}0.1108^{* * * *} \\
(0.0342)\end{array}$ & $\begin{array}{l}0.1152 * * * \\
(0.0348)\end{array}$ \\
\hline \# of floors & $\begin{array}{l}0.0639 \text { *** } \\
(0.0019)\end{array}$ & $\begin{array}{l}0.0654 * * * \\
(0.0020)\end{array}$ & $\begin{array}{l}0.0658 * * * \\
(0.0020)\end{array}$ & $\begin{array}{l}0.0654 * * * * \\
(0.0023)\end{array}$ & $\begin{array}{l}0.0507 * * * * \\
(0.0102)\end{array}$ & $\begin{array}{l}0.0498 * * * \\
(0.0104)\end{array}$ \\
\hline penthouse & $\begin{array}{l}0.0322^{* * * *} \\
(0.0062)\end{array}$ & $\begin{array}{l}0.0362^{* * * *} \\
(0.0064)\end{array}$ & $\begin{array}{l}0.0365^{* * * *} \\
(0.0064)\end{array}$ & $\begin{array}{l}0.0328 * * * \\
(0.0070)\end{array}$ & $\begin{array}{l}0.0491^{*} \\
(0.0276)\end{array}$ & $\begin{array}{l}0.0496 * \\
(0.0284)\end{array}$ \\
\hline percentage of dwellings with sewage coverage & $\begin{array}{l}-0.1092 \\
(0.1166)\end{array}$ & $\begin{array}{l}-0.1575 \\
(0.1225)\end{array}$ & $\begin{array}{l}-0.1638 \\
(0.1191)\end{array}$ & $\begin{array}{l}-0.2035 \\
(0.1289)\end{array}$ & $\begin{array}{l}-0.2684 \\
(0.2079)\end{array}$ & $\begin{array}{l}-0.2683 \\
(0.2070)\end{array}$ \\
\hline percentage of dwellings without bathrooms & $\begin{array}{l}-1.8126 \\
(2.0933)\end{array}$ & $\begin{array}{l}-1.6787 \\
(2.1472)\end{array}$ & $\begin{array}{l}-1.8362 \\
(2.1507)\end{array}$ & $\begin{array}{l}-0.5558 \\
(2.1785)\end{array}$ & $\begin{array}{l}-6.4494 \\
(6.2692)\end{array}$ & $\begin{array}{l}-7.8416 \\
(6.6370)\end{array}$ \\
\hline percentage of dwellings with garbage services coverage & $\begin{array}{l}0.0884 \\
(0.1520)\end{array}$ & $\begin{array}{l}0.0690 \\
(0.1503)\end{array}$ & $\begin{array}{l}0.0611 \\
(0.1501)\end{array}$ & $\begin{array}{l}0.1577 \\
(0.1582)\end{array}$ & $\begin{array}{l}0.9216 \\
(0.6683)\end{array}$ & $\begin{array}{l}0.8895 \\
(0.6738)\end{array}$ \\
\hline percentage of dwellings with water system coverage & $\begin{array}{l}0.0722 \\
(0.2516)\end{array}$ & $\begin{array}{l}-0.0136 \\
(0.2559)\end{array}$ & $\begin{array}{l}0.0068 \\
(0.2565)\end{array}$ & $\begin{array}{l}0.0261 \\
(0.2730)\end{array}$ & $\begin{array}{l}-0.7474 \\
(0.7173)\end{array}$ & $\begin{array}{l}-0.7903 \\
(0.7231)\end{array}$ \\
\hline ln of income & $\begin{array}{l}0.0071 \\
(0.0153)\end{array}$ & $\begin{array}{l}-0.0080 \\
(0.0113)\end{array}$ & $\begin{array}{l}-0.0034 \\
(0.0113)\end{array}$ & $\begin{array}{l}-0.0123 \\
(0.0132)\end{array}$ & $\begin{array}{l}-0.0936 \\
(0.0738)\end{array}$ & $\begin{array}{l}-0.0757 \\
(0.0769)\end{array}$ \\
\hline ln of population density in sector & $\begin{array}{l}-0.0355 * * * \\
(0.0121)\end{array}$ & $\begin{array}{l}-0.0388 * * * \\
(0.0124)\end{array}$ & $\begin{array}{l}-0.0414 * * * \\
(0.0123)\end{array}$ & $\begin{array}{l}-0.0414 * * * \\
(0.0138)\end{array}$ & $\begin{array}{l}-0.0399 \\
(0.0539)\end{array}$ & $\begin{array}{l}-0.0299 \\
(0.0543)\end{array}$ \\
\hline municipality of Sao Paulo & $\begin{array}{l}0.1062 * * * \\
(0.0295)\end{array}$ & $\begin{array}{l}0.1416 * * * \\
(0.0300)\end{array}$ & $\begin{array}{l}0.1717 * * * \\
(0.0295)\end{array}$ & $\begin{array}{l}0.1783 * * * \\
(0.0324)\end{array}$ & $\begin{array}{l}0.1209 \\
(0.1213)\end{array}$ & $\begin{array}{l}0.1608 \\
(0.1299)\end{array}$ \\
\hline ln of distance from Sao Paulo downtown & $\begin{array}{l}-0.0619 * * * \\
(0.0118)\end{array}$ & $\begin{array}{l}-0.0623 * * * \\
(0.0118)\end{array}$ & $\begin{array}{l}-0.0714 * * * \\
(0.0118)\end{array}$ & $\begin{array}{l}-0.0695^{* * *} \\
(0.0124)\end{array}$ & $\begin{array}{l}-0.7316^{* * *} \\
(0.2167)\end{array}$ & $\begin{array}{l}-0.7145 * * * \\
(0.2167)\end{array}$ \\
\hline Rodoanel west section: announcement & $\begin{array}{l}-0.3021 * * * \\
(0.0285)\end{array}$ & & & & & \\
\hline Rodoanel west section: construction & $\begin{array}{l}-0.3780 * * * \\
(0.0357)\end{array}$ & & & & & \\
\hline Rodoanel west section: delivery & $\begin{array}{l}-0.7116 * * * \\
(0.0268)\end{array}$ & & & & & \\
\hline
\end{tabular}

${ }^{16}$ Robust standard errors in parethesis. * $\mathrm{p}<0.10, * * \mathrm{p}<0.05, * * * \mathrm{p}<0.01$ 
Table 8 - Estimation results (cont.)

\begin{tabular}{|c|c|c|c|c|c|c|}
\hline Var. Dep.: Ln $(p)$ & $\begin{array}{c}\text { Regression } \\
1\end{array}$ & $\begin{array}{c}\text { Regression } \\
2\end{array}$ & $\begin{array}{c}\text { Regression } \\
3\end{array}$ & $\begin{array}{c}\text { Regression } \\
4\end{array}$ & $\begin{array}{c}\text { Regression } \\
5\end{array}$ & $\begin{array}{c}\text { Regression } \\
6\end{array}$ \\
\hline \multicolumn{7}{|l|}{ (cont.) } \\
\hline near till $2500 \mathrm{~m}$ west from Rodoanel & $\begin{array}{l}-2.3469^{* * *} \\
(0.1355)\end{array}$ & $\begin{array}{l}-2.3013 * * * \\
(0.1329)\end{array}$ & $\begin{array}{l}-2.2954 * * * \\
(0.1388)\end{array}$ & $\begin{array}{l}-2.3141 * * * \\
(0.1402)\end{array}$ & $\begin{array}{l}-2.3443 * * * \\
(0.2155)\end{array}$ & $\begin{array}{l}-2.3399 * * * \\
(0.2209)\end{array}$ \\
\hline near till $2500 \mathrm{~m}$ east from Rodoanel & $\begin{array}{l}0.1421 \\
(0.1933)\end{array}$ & $\begin{array}{l}0.0540 \\
(0.1588)\end{array}$ & $\begin{array}{l}0.0694 \\
(0.1588)\end{array}$ & $\begin{array}{l}0.0603 \\
(0.1607)\end{array}$ & $\begin{array}{l}-0.3879 \\
(0.2436)\end{array}$ & $\begin{array}{l}-0.6101^{*} \\
(0.3536)\end{array}$ \\
\hline near beyond $2500 \mathrm{~m}$ west from Rodoanel & $\begin{array}{l}-0.0254 \\
(0.1677)\end{array}$ & $\begin{array}{l}0.0174 \\
(0.1667)\end{array}$ & & & & \\
\hline near between $2500 \mathrm{~m}$ and $5000 \mathrm{~m}$ east from Rodoanel & $\begin{array}{l}-0.1670 \\
(0.1313)\end{array}$ & $\begin{array}{l}-0.0905 \\
(0.1111)\end{array}$ & & & & \\
\hline announcement*proximity $2500 \mathrm{~m}$ west & $\begin{array}{l}0.0000 \\
(0.0000)\end{array}$ & & & & & \\
\hline announcement*proximity $2500 \mathrm{~m}$ east & $\begin{array}{l}-0.1043 \\
(0.3176)\end{array}$ & & & & & \\
\hline announcement*proximity beyond $2500 \mathrm{~m}$ west & $\begin{array}{l}0.0000 \\
(0.0000)\end{array}$ & & & & & \\
\hline announcement*proximity $2500 \mathrm{~m}-5000 \mathrm{~m}$ east & $\begin{array}{l}0.3246 \\
(0.2154)\end{array}$ & & & & & \\
\hline construction*proximity $2500 \mathrm{~m}$ west & $\begin{array}{l}1.3266^{* * * *} \\
(0.1498)\end{array}$ & & & & & \\
\hline construction*proximity $2500 \mathrm{~m}$ east & $\begin{array}{l}-1.0506 \\
(0.6404)\end{array}$ & & & & & \\
\hline construction*proximity beyond $2500 \mathrm{~m}$ west & $\begin{array}{l}-0.8552 * * \\
(0.3855)\end{array}$ & & & & & \\
\hline construction*proximity $2500 \mathrm{~m}-5000 \mathrm{~m}$ east & $\begin{array}{l}0.0889 \\
(0.4594)\end{array}$ & & & & & \\
\hline delivery*proximity $2500 \mathrm{~m}$ west & $\begin{array}{l}0.5434 \\
(0.4753)\end{array}$ & & & & & \\
\hline delivery*proximity $2500 \mathrm{~m}$ east & $\begin{array}{l}-0.3324 \\
(0.2179)\end{array}$ & & & & & \\
\hline delivery*proximity beyond $2500 \mathrm{~m}$ west & $\begin{array}{l}-0.6044 * * * \\
(0.2073)\end{array}$ & & & & & \\
\hline delivery*proximity $2500 \mathrm{~m}-5000 \mathrm{~m}$ east & $\begin{array}{l}-0.3397 * \\
(0.1957)\end{array}$ & & & & & \\
\hline after construction has started & & $\begin{array}{l}-0.5047 * * * * \\
(0.0227)\end{array}$ & $\begin{array}{l}-0.5143^{* * * *} \\
(0.0226)\end{array}$ & $\begin{array}{l}-0.5610^{* * *} \\
(0.0252)\end{array}$ & $\begin{array}{l}-0.9013^{* * *} \\
(0.1535)\end{array}$ & $\begin{array}{l}-0.8750^{* * *} \\
(0.1613)\end{array}$ \\
\hline after*proximity $2500 \mathrm{~m}$ east & & $\begin{array}{l}-0.4671^{*} \\
(0.2407)\end{array}$ & $\begin{array}{l}-0.4461^{*} \\
(0.2400)\end{array}$ & $\begin{array}{l}-0.3998^{*} \\
(0.2401)\end{array}$ & $\begin{array}{l}0.3357 \\
(0.2831)\end{array}$ & $\begin{array}{l}0.3177 \\
(0.3578)\end{array}$ \\
\hline after*proximity $2500 \mathrm{~m}-5000 \mathrm{~m}$ east & & $\begin{array}{l}-0.3889 * * \\
(0.1871)\end{array}$ & & & & \\
\hline after*proximity $2500 \mathrm{~m}$ west & & $\begin{array}{l}0.6227 \\
(0.4133)\end{array}$ & $\begin{array}{l}0.6666 \\
(0.4146)\end{array}$ & $\begin{array}{l}0.7217^{*} \\
(0.4140)\end{array}$ & $\begin{array}{l}0.9496 * * \\
(0.4317)\end{array}$ & $\begin{array}{l}0.9084 * \\
(0.4701)\end{array}$ \\
\hline after*proximity beyond $2500 \mathrm{~m}$ west & & $\begin{array}{l}-0.7335^{* * * *} \\
(0.2031)\end{array}$ & & & & \\
\hline R-squared & 0.43 & 0.41 & 0.40 & 0.42 & 0.58 & 0.58 \\
\hline $\mathrm{N}$ & 7212 & 7212 & 7212 & 5833 & 502 & 493 \\
\hline
\end{tabular}

